\title{
Analysis And Design of Decision Support System in Major Assignment at Buddhi High School Using AHP and SAW Methods
}

\author{
Devita Amalia Pertiwi ${ }^{1}$, Benny Daniawan ${ }^{2}$, Yuki Gunawan ${ }^{3}$ \\ ${ }^{1,2,3}$ Information System, Faculty of Sains and Technology, Buddhi DharmaUniversity, Tangerang, Indonesia
}

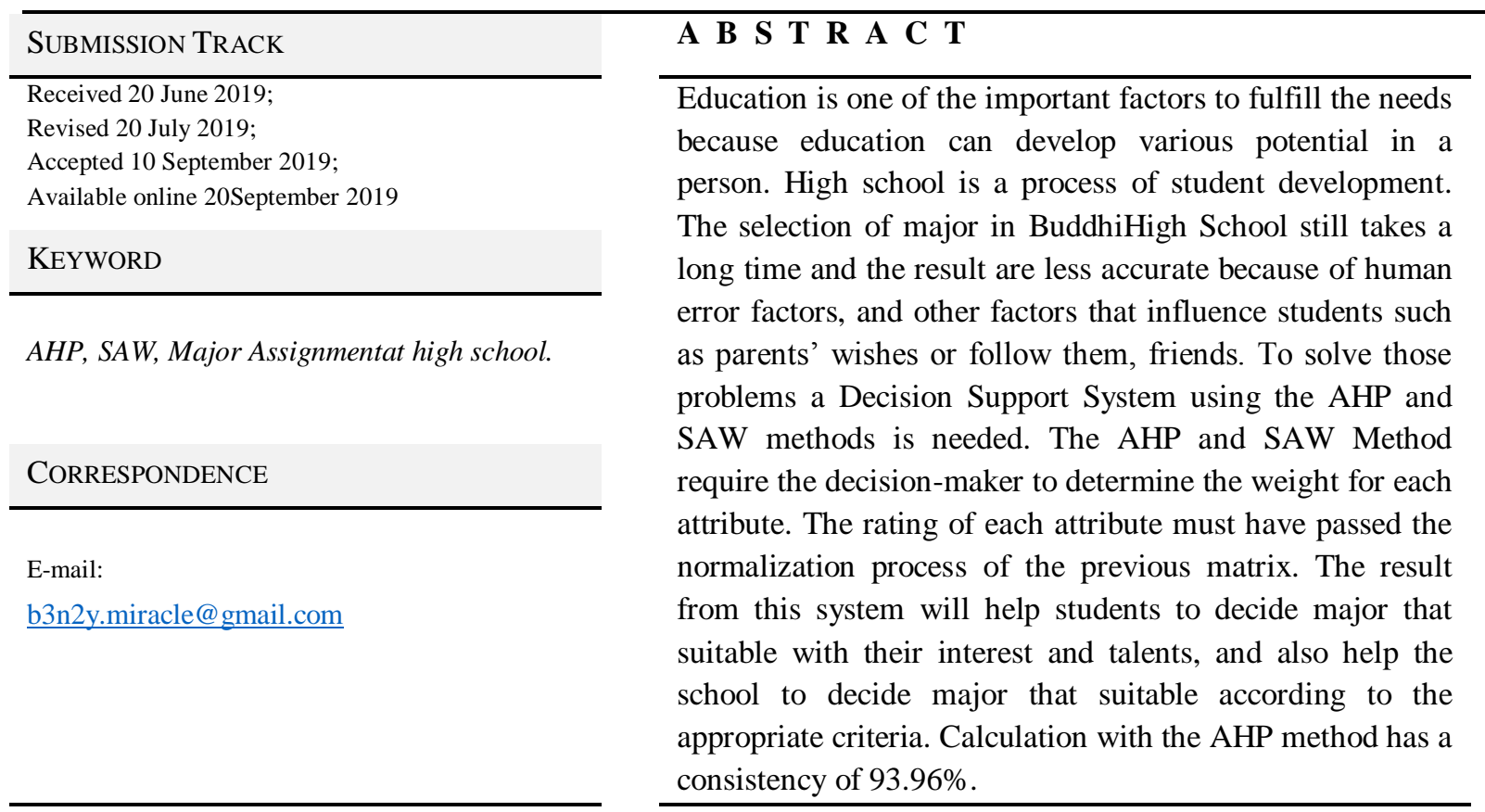

\section{INTRODUCTION}

Based on the Regulation of the Minister of Education and Culture of the Republic of Indonesia Number 24 of 2016 concerning Core Competencies and Basic Competencies of Learning in the 2013 Curriculum. In the 2013 Senior High School curriculum structure, there are many subjects, subjects are divided into 2, compulsory subjects, and elective subjects. In subjects of choice, students can choose subjects that are of interest and according to their learning abilities. Also, it provides opportunities to develop the potential of students by their talents, interests, and academic potential[1]. The majors in the 2013 Curriculum for High Schools (SMA) are no longer done in class $\mathrm{XI}$, but rather starting in class $\mathrm{X}$. This policy is said by many to be a challenge in its application, both for the school and the students. This is because most students have not fully understood and explored subjects at the high school level so they have not been able to ascertain the desired majors. Also, high school students sometimes choose majors that are not by their abilities, talents, interests and academic achievements. This 
might be due to the confusion of students when given majors.

Many of them just follow their friends who choose one of the majors or even submit their choices to their parents. Determination of majors based on these factors will certainly cause students to feel sorry for choosing a course and cause a decline in the quality and academic achievement of students due to the majors not by their talents, interests and academic potential [2] [12].

At Buddhi High School Tangerang has two majors that is Science and Social Sciences. The process of determining this department is based on the report card grades, the results of tests in academic potential, the value of the National Examination on junior high, and student interest.

The current selection process for majors has a drawback, including requiring quite a long time and also the results obtained are less accurate because there could be a lot of errors due to the unavailability of special applications to support these calculations. By using the AHP and SAW methods where the AHP method will be used as a weighting criterion and the SAW method is used as an alternative ranking.

\section{LITERATURES REVIEW}

In Budi Nugrohojournal, said that the Method (WP) Weighted Product can be implemented in the Decision Support System for Student Majors in Senior High School 1 Grobogan. It can be used to support the student majors process in Grobogan 1 High School based on the best alternative of student achievement scores[3].

In Firliana journal, said that student evaluations using profile matching methods with academic and non-academic criteria can give major recommendations by calculating the value of student competency Gaps and majors standards according to the criteria weights of each department and paying attention to Core Factors and Secondary Factors. The highest total value from the sum of academic and non-academic criteria is the recommended major. With the application of the department's recommendations can help the Madrasas in evaluating the potential of students[4].

In the journal Supriadi, the author concluded with the existence of a decision support system, the selection of majors in Merangin SMAN 8 students can be done easily and effectively because the department obtained by students in accordance with the interests and abilities of students, and can reduce errors in the selection of majors in students[5].

In the Daniawan journal, that evaluating lecturers' performance in teaching using the AHP and SAW methods can provide a level of consistency $96.75 \%$ from the 10 assessment indicators of 28 lecturers teaching 47 courses. By combining these two methods will be able to provide more accurate results and it is very unlikely the lecturers will have the same rating ranking[6].

\section{FRAMEWORK}

The framework as follows: 


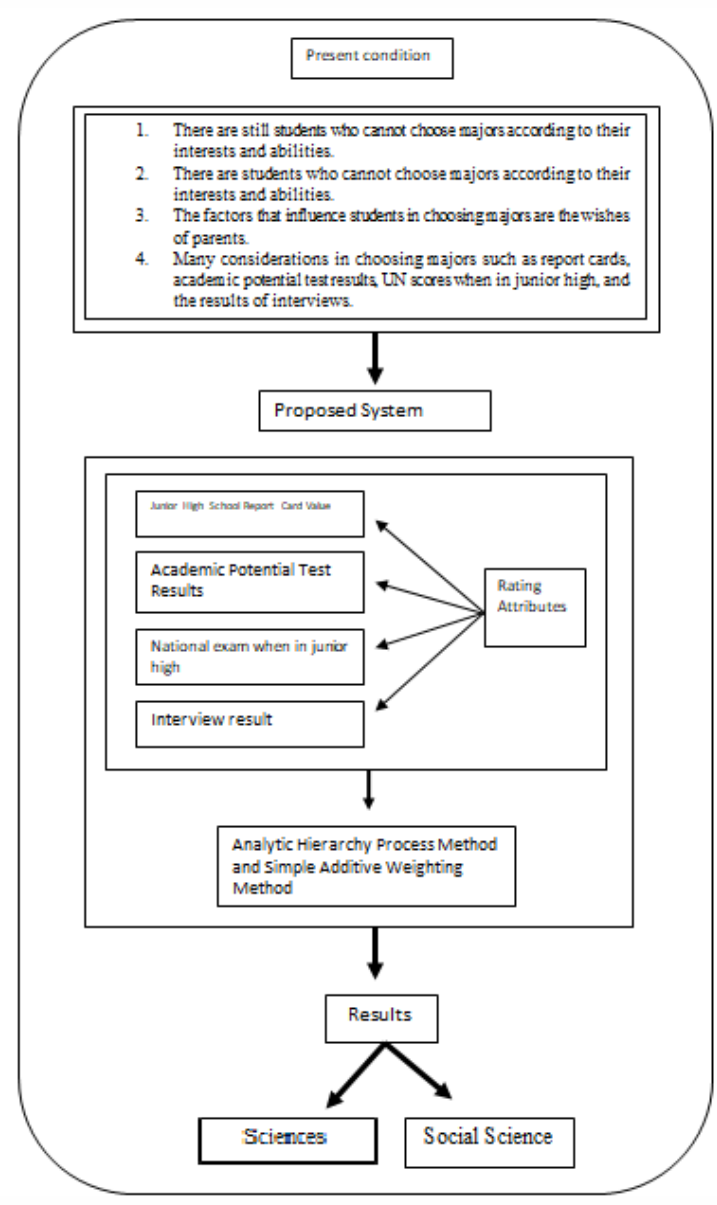

Figure 1 Framework

\section{METHODS}

Systems Development Life Cycle (SDLC) According to Bassil, the SDLC Waterfall Model is a sequential software development process where the process is from top to bottom (such as a waterfall) through the stages that must be carried out for successful software development[7].

\section{a. Analysis Phase}

This stage is an analysis of system requirements. The data needed for this analysis phase is obtained from the results of the interview process, questionnaire, and literature study.

a. Design Phase

This stage will process the results of the system requirements analysis into a form of software design, as well as problem-solving (problem-solving) for a device solution.

b. Implementation phase

This stage is the process of changing all system requirements and software design, as well as problem-solving into an educational environment. Where the education environment uses the PHP programming language and MySql database.

c. Testing phase

This stage is the process of testing the system, to find out whether the system is running well by the system and software design

d. Maintenance phase

This stage is a process to correct the errors that occur when the system has been applied.

\section{Analytic Hierarchy Process (AHP)}

According to PawelTadeusz and Kazibudzki, Analytic Hierarchy Process (AHP) is a multi-criteria decision making with the support of methodologies that have been recognized and accepted as priorities which in theory can provide different answers to decision-making problems and rank alternative solutions[8].

Following are the steps in AHP according to Saaty :

1. Create a hierarchical structure.

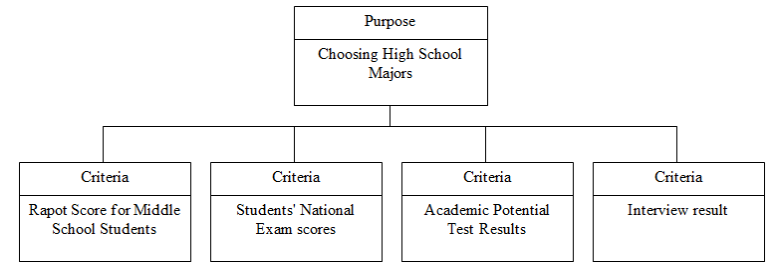

\section{Figure 2 Hierarchical structure}

2. Define a pairwise comparison, where there is a scale of comparison: 
Table 1 Comparison scale

\begin{tabular}{|l|c|}
\hline Preference Level & Score \\
\hline Absolute Very Important & 9 \\
\hline Very Important & 7 \\
\hline Very important & 5 \\
\hline Quite important & 3 \\
\hline Equally Important & $2,4,6,8$ \\
\hline $\begin{array}{l}\text { Values between 2 adjacent } \\
\text { considerations }\end{array}$ \\
\hline
\end{tabular}

3. Normalize data

$$
\begin{gathered}
r_{i j}=\sqrt{(a i 1)(a i 2) \ldots \ldots(a i j)} \\
r=\left(\begin{array}{c}
r 1 \\
r 2 \\
\cdot \\
\cdot \\
r n
\end{array}\right)
\end{gathered}
$$

According to Marimin, in the AHP method, an iteration is performed at least 3 times, provided that the eigenvalue has not changed to 4 digits behind the comma[10].

4. Calculate Vector Priority and Row Matrix

$$
P . V=\frac{\mathrm{r}_{\mathrm{ij}}}{\sum \mathrm{r}_{\mathrm{ij}}}
$$

5. Calculate Vector Consistency

$$
C . V=\frac{\text { Row Matrix }}{P . V}
$$

6. Calculate the eigenvector value

$$
\lambda \text { maks }=\frac{\sum \mathrm{C} . \mathrm{V}}{\mathrm{n}}
$$

7. Estimate Consistency of Index

$$
C . I=\frac{(\lambda \text { maks }-\mathrm{n})}{(n-1)}
$$

8. Calculate the Consistency Ratio (C.R) based on the R.I table

$$
C \cdot R=\frac{C . I}{R \cdot I}
$$

Table 2 Random index

\begin{tabular}{|l|l|l|l|l|l|l|l|l|}
\hline $\mathrm{n}$ & 1 & 2 & 3 & 4 & 5 & 6 & 7 & 8 \\
\hline $\mathrm{RI}$ & 0 & 0 & 0,58 & 0,9 & 1,12 & 1,24 & 1,32 & 1,41 \\
\hline
\end{tabular}

\begin{tabular}{|l|l|l|l|l|l|l|l|}
\hline $\mathrm{n}$ & 9 & 10 & 11 & 12 & 13 & 14 & 15 \\
\hline $\mathrm{RI}$ & 1,45 & 1,49 & 1,51 & 1,48 & 1,56 & 1,57 & 1,59 \\
\hline
\end{tabular}

9. Test the consistency of the hierarchy. If it does not meet with $\mathrm{CR}<0.1$ then the assessment must be repeated[9].

\section{Simple Additive Weighting (SAW)}

According to Eniyati, the SAW Method is often also known as the weighted sum method. The basic concept of the SAW method is to find a weighted sum of the performance ratings for each alternative on all attributes. The SAW method requires the decision matrix normalization process $(\mathrm{X})$ to a scale that can be compared with all available alternative ratings[11].

Following are the steps in SAW:

1. Normalize

2. Finding the Maximum and Minimum Value

$$
r_{i j}=\left\{\begin{array}{l}
\frac{X_{i j}}{\operatorname{Max}_{i X_{i j}}} \\
\frac{\operatorname{Min}_{i X_{i j}}}{X_{i j}}
\end{array}\right.
$$

3. Calculating the Preference Value

$$
V_{i}=\sum_{j=1}^{n} w_{j} r_{i j}
$$


In this study only used 4 assessment criteria, and 15 student data used to rank.

\section{RESULT}

\section{Analytic Hierarchy Process}

The weighting questionnaire was filled out by the vice principal Curriculum on a comparative scale

Table 3 Comparison scale value

\begin{tabular}{|l|c|c|c|c|}
\hline & $\begin{array}{c}\text { Junior } \\
\text { High } \\
\text { School } \\
\text { Report } \\
\text { Card } \\
\text { Value }\end{array}$ & $\begin{array}{c}\text { Junior High } \\
\text { School } \\
\text { National } \\
\text { Examinatio } \\
\text { n Score }\end{array}$ & $\begin{array}{c}\text { Academic } \\
\text { Potential } \\
\text { Value }\end{array}$ & $\begin{array}{c}\text { Student } \\
\text { Interview } \\
\text { Results }\end{array}$ \\
\hline $\begin{array}{l}\text { Junior High } \\
\text { School Report } \\
\text { Card Value }\end{array}$ & 1.0000 & 3.0000 & 5.0000 & 7.0000 \\
\hline $\begin{array}{l}\text { Junior High } \\
\text { School National } \\
\begin{array}{l}\text { Examination } \\
\text { Score }\end{array}\end{array}$ & 0.3333 & 1.0000 & 3.0000 & 5.0000 \\
\hline $\begin{array}{l}\text { Academic } \\
\text { Potential Value }\end{array}$ & 0.2000 & 0.3333 & 1.0000 & 3.0000 \\
\hline $\begin{array}{l}\text { Student } \\
\text { Interview } \\
\text { Results }\end{array}$ & 0.1429 & 0.2000 & 0.3333 & 1.0000 \\
\hline Total & 1.6762 & 4.5333 & 9.3333 & 16.0000 \\
\hline
\end{tabular}

1. A pairwise comparison matrix will be processed to determine the ranking of the criteria, namely by determining the eigenvalue. The procedure for obtaining eigenvalues is:

a. Squaring the matrix

b. Count the number of values from each row, then normalize.

1st iteration:

\section{Table 4 1st iteration}

$\begin{array}{lll}3.0000 & 5.0000 & 7.0000 \\ 1.0000 & 3.0000 & 5.0000 \\ 0.3333 & 1.0000 & 3.0000 \\ 0.2000 & 0.3333 & 1.0000\end{array}|\times| \begin{array}{llll}1.0000 & 3.0000 & 5.0000 & 7.0000 \\ 0.3333 & 1.0000 & 3.0000 & 5.0000 \\ 0.2000 & 0.3333 & 1.0000 & 3.0000 \\ 0.1429 & 0.2000 & 0.3333 & 1.0000\end{array} \mid$
$=\left|\begin{array}{llll}4.0000 & 9.0667 & 21.3333 & 44.0000 \\ 1.9810 & 4.0000 & 9.3333 & 21.3333 \\ 0.9397 & 1.8667 & 4.0000 & 9.0667 \\ 0.4190 & 0.9397 & 1.9810 & 4.0000\end{array}\right|$

Add up the values for each matrix line and calculate the normalized return value:

Table 5 Normalization Result 1

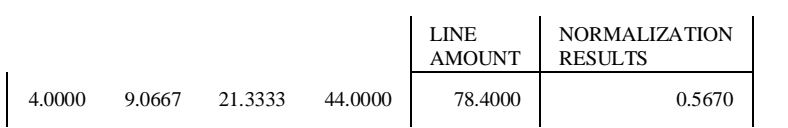

$$
\begin{array}{|rrrr|r|r|}
1.9810 & 4.0000 & 9.3333 & 21.3333 & 36.6476 & 0.2651 \\
0.9397 & 1.8667 & 4.0000 & 9.0667 & 15.8730 & 0.1148 \\
0.4190 & 0.9397 & 1.9810 & 4.0000 & 7.3397 & 0.0531 \\
& & & \text { Total } & 138.2603 & 1.0000
\end{array}
$$

2nd iteration:

Table 6 2nd iteration

$$
\begin{array}{|l}
\begin{array}{llll}
4.0000 & 9.0667 & 21.3333 & 44.0000 \\
1.9810 & 4.0000 & 9.3333 & 21.3333 \\
0.9397 & 1.8667 & 4.0000 & 9.0667 \\
0.4190 & 0.9397 & 1.9810 & 4.0000
\end{array}|\times| \times \mid \begin{array}{lllll}
4.0000 & 9.0667 & 21.3333 & 44.0000 \\
0.9810 & 4.0000 & 9.3333 & 21.3333 \\
0.9397 & 1.8667 & 4.0000 & 9.0667 \\
0.4190 & 0.9397 & 1.9810 & 4.0000
\end{array} \\
=\left|\begin{array}{llll}
72.4453 & 153.7016 & 342.4508 & 738.8444 \\
33.5577 & 71.4294 & 159.1873 & 342.4508 \\
15.0146 & 19.7452 & 71.4294 & 153.7016 \\
7.0753 & 15.0146 & 33.5577 & 72.4453
\end{array}\right|
\end{array}
$$

Add up the values for each matrix line and

\begin{tabular}{|c|c|c|c|c|}
\hline & & & $\begin{array}{l}\text { LINE } \\
\text { AMOUNT }\end{array}$ & $\begin{array}{l}\text { NORMALIZATION } \\
\text { RESULTS }\end{array}$ \\
\hline 153.7016 & 342.2508 & 738.8444 & 1307.4421 & 0.5679 \\
\hline 71.4294 & 159.1873 & 342.4508 & 606.6252 & 0.2635 \\
\hline 19.7452 & 71.4294 & 153.7016 & 259.8908 & 0.1129 \\
\hline \multirow[t]{2}{*}{15.0146} & 33.5577 & 72.4453 & 128.0929 & 0.0556 \\
\hline & & Total & 2302.0510 & 1.0000 \\
\hline
\end{tabular}
calculate the normalized return value:

\section{Table 7 Normalization Result 2}

Calculate the difference in eigenvalue before and after the present eigenvalue

$0.5670-0.5679=-0.0009$

$0.2651-0.2635=0.0016$

$0.1148-0.1129=0.0019$

$0.0531-0.0556=-0.0025$

3rd iteration:

\section{Table 8 3rd iteration}

\begin{tabular}{|llll}
72.4453 & 153.7016 & 342.4508 & 738.8444 \\
33.5577 & 71.4294 & 159.1873 & 342.4508 \\
15.0146 & 19.7452 & 71.4294 & 153.7016 \\
7.0753 & 15.0146 & 33.5577 & 72.4453
\end{tabular}$|\times|$\begin{tabular}{lllll|}
72.4453 & 153.7016 & 342.4508 & 738.8444 \\
15577 & 71.4294 & 159.1873 & 342.4508 \\
7.0753 & 19.7452 & 71.4294 & 153.7016 \\
& & 15.0146 & 33.5577 & 72.4453
\end{tabular}

Add up the values for each matrix line and calculate the normalized return value:

Table 9 Normalization Result 3 
Total $|1.0000 \quad| 7$. Test consistency of the hierarchy

Calculate the difference in eigenvalue before

Consistency hierarchy $=0,0465<0,1$

and after the present eigenvalue

$0.5679-0.5715=-0.0036$

$0.2635-0.2652=-0.0017$

$0.1129-0.1074=0.0055$

$0.0556-0.0559=-0.0003$

2. Calculate Priority Vectors

Table 10 Priority Vectors

\begin{tabular}{|l|llll} 
Kriteria & 1.0000 & 3.0000 & 5.0000 & 7.0000 \\
0.3333 & 1.0000 & 3.0000 & 5.0000 \\
0.2000 & 0.3333 & 1.0000 & 3.0000 \\
0.1429 & 0.2000 & 0.3333 & 1.0000
\end{tabular}$|\times| \begin{aligned} & 0.5715 \\
& 0.2652 \\
& 0.1074 \\
& 0.0559\end{aligned}$

$=\left|\begin{array}{l}2.2956 \\ 1.0576 \\ 0.4779 \\ 0.2264\end{array}\right|$

\section{Calculate Vector Consistency}

VectorConsistency $=\frac{2.2956}{0.5715} \frac{1.0576}{0.2652} \frac{0.4779}{0.1074} \frac{0.2264}{0.0559}$

Vector

$=\begin{array}{llll}4.0171 & 3.9879 & 4.4480 & 4.0490\end{array}$

Consistency

4. Calculate the eigenvector value

$$
\begin{gathered}
\lambda \text { maks }=\frac{4.0171+3.9879+4.480+4.0490}{4.0000} \\
\lambda \text { maks }=\frac{16.5020}{4.0000} \\
\lambda \text { maks }=4.1255
\end{gathered}
$$

5. Estimate Consistency of Index

$$
\begin{gathered}
C . I=\frac{(4.1255-4.0000)}{(4 \cdot 0000-1.0000)} \\
C . I=\frac{0,1255}{3 \cdot 0000} \\
C . I=0,0418
\end{gathered}
$$

6. Calculate Consistency Ratio (C.R)

$$
\begin{aligned}
& C \cdot R=\frac{0,0418}{0,9000} \\
& C . R=0,0465
\end{aligned}
$$

\section{Simple Additive Weighting}

Table 11 Student scores

\begin{tabular}{|c|l|l|l|l|l|}
\hline No & Name & C1 & C2 & C3 & C4 \\
\hline 1 & A1 & 69.33 & 84.63 & 74.24 & 100 \\
\hline 2 & A2 & 58.62 & 59.00 & 60.25 & 100 \\
\hline 3 & A3 & 78.33 & 78.00 & 80.00 & 100 \\
\hline 4 & A4 & 63.67 & 65.75 & 68.00 & 100 \\
\hline 5 & A5 & 76.00 & 78.25 & 75.00 & 100 \\
\hline 6 & A6 & 77.34 & 65.00 & 75.60 & 100 \\
\hline 7 & A7 & 67.78 & 70.88 & 72.31 & 100 \\
\hline 8 & A8 & 80.00 & 77.25 & 83.41 & 100 \\
\hline 9 & A9 & 62.45 & 60.00 & 67.23 & 100 \\
\hline 10 & A10 & 53.45 & 58.32 & 60.23 & 100 \\
\hline 11 & A11 & 55.65 & 54.51 & 52.00 & 100 \\
\hline 12 & A12 & 54.55 & 55.80 & 53.30 & 100 \\
\hline 13 & A13 & 52.35 & 54.98 & 55.44 & 100 \\
\hline 14 & A14 & 55.45 & 54.00 & 55.74 & 100 \\
\hline 15 & A15 & 53.23 & 55.67 & 57.65 & 100 \\
\hline
\end{tabular}

Table 12 Matrix Normalization Results

\begin{tabular}{|l|l|l|l|l|}
\cline { 2 - 5 } \multicolumn{1}{l|}{} & \multicolumn{2}{l}{ Normalization } \\
\hline Alternative & $\mathrm{C} 1$ & $\mathrm{C} 2$ & \multicolumn{1}{l}{$\mathrm{C} 3$} & $\mathrm{C} 4$ \\
\hline $\begin{array}{l}\text { Weight } \\
\text { Normalization }\end{array}$ & 0.5715 & 0.2652 & 0.1074 & 0.0559 \\
\hline Alternative 1 & 0.4952 & 0.2652 & 0.0956 & 0.0559 \\
\hline Alternative 2 & 0.4187 & 0.1849 & 0.0776 & 0.0559 \\
\hline Alternative 3 & 0.5595 & 0.2444 & 0.1030 & 0.0559 \\
\hline Alternative 4 & 0.4548 & 0.2060 & 0.0876 & 0.0559 \\
\hline Alternative 5 & 0.5429 & 0.2452 & 0.0966 & 0.0559 \\
\hline Alternative 6 & 0.5525 & 0.2037 & 0.0974 & 0.0559 \\
\hline Alternative 7 & 0.4842 & 0.2221 & 0.0931 & 0.0559 \\
\hline Alternative 8 & 0.5715 & 0.2421 & 0.1074 & 0.0559 \\
\hline Alternative 9 & 0.4461 & 0.1880 & 0.0914 & 0.0559 \\
\hline Alternative 10 & 0.3818 & 0.1827 & 0.0819 & 0.0559 \\
\hline Alternative 11 & 0.3975 & 0.1708 & 0.0670 & 0.0559 \\
\hline Alternative 12 & 0.3897 & 0.1749 & 0.0687 & 0.0559 \\
\hline Alternative 13 & 0.3739 & 0.1723 & 0.0714 & 0.0559 \\
\hline Alternative 14 & 0.3961 & 0.1692 & 0.0718 & 0.0559 \\
\hline Alternative 15 & 0.3802 & 0.1744 & 0.0743 & 0.0559 \\
\hline
\end{tabular}


Table 13 Vector Preferences and Ranking

\begin{tabular}{|l|r|r|}
\hline \multicolumn{1}{|c|}{ Alternative } & \multicolumn{1}{|c|}{ Scores } & \multicolumn{1}{|c|}{ Rank } \\
\hline Alternative 1 & 0.9120 & 4 \\
\hline Alternative 2 & 0.7371 & 9 \\
\hline Alternative 3 & 0.9629 & 2 \\
\hline Alternative 4 & 0.8043 & 7 \\
\hline Alternative 5 & 0.9406 & 3 \\
\hline Alternative 6 & 0.9094 & 5 \\
\hline Alternative 7 & 0.8553 & 6 \\
\hline Alternative 8 & 0.9769 & 1 \\
\hline Alternative 9 & 0.7815 & 8 \\
\hline Alternative 10 & 0.7024 & 12 \\
\hline Alternative 11 & 0.6950 & 11 \\
\hline Alternative 12 & 0.6929 & 10 \\
\hline Alternative 13 & 0.6775 & 15 \\
\hline Alternative 14 & 0.6970 & 13 \\
\hline Alternative 15 & 0.6890 & 14 \\
\hline
\end{tabular}

The minimum value to enter the science department is 0.7 . Where the standard value is determined by the school, and if the prevalence value is less than 0.7 , it will go into the Social Sciences major.

This journal used 15 alternatives (students) out of a total of 120 students. From the tested data, 10 students entered the science department, and 5 students entered the social science department.

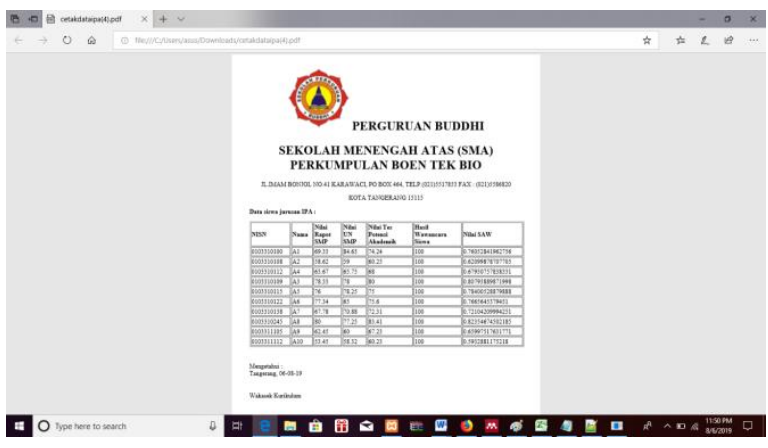

Figure 3 student major report in Sciences

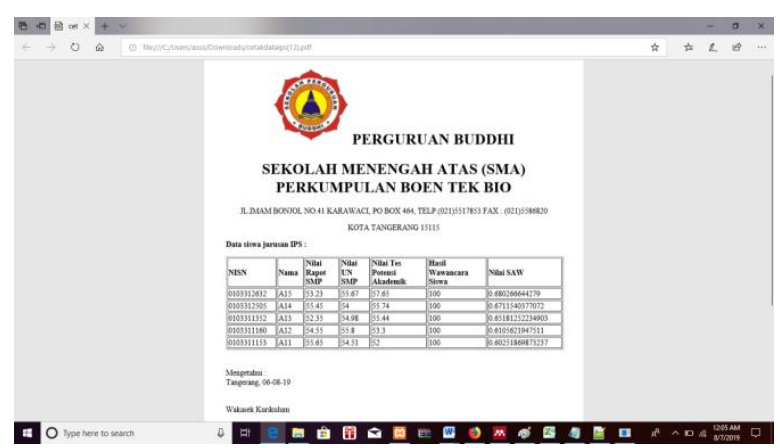

Figure 4 student major report in social studies

\section{DISCUSSION}

\section{Combination of AHP and SAW Methods}

The advantages of the AHP method according to Daniawan, is to have a hierarchical structure so that the problem is more structured, there is a measurement scale to determine the value of the comparison of interests, has a careful calculation and has a measure of consistency in filling out the questionnaire filled out by respondents. Meanwhile, the disadvantage of the AHP method is that the calculation is more complicated, the method is mathematical without statistical testing so there is no confidence limit of the correctness of the model formed and to make improvements to the decision must start again from the initial stage[6].

The advantage of the SAW method is that it has an easy to understand the calculation, a matrix normalization calculation by the attribute value (between benefit and cost value). The disadvantage of the SAW method is that the calculations are performed using crisp or fuzzy numbers, used in local weighting.

From the consideration of the advantages and disadvantages of each method, the AHP and SAW methods were combined as a method for the decision support system for majors atBuddhi High School. 
AHP method is used in calculating the weighting criteria and the SAW method is used in calculating alternative weighting.

\section{CONCLUSION}

a. With this Decision Support System for determining majors, the school will get direction in determining student majors according to their interests and talents.

b. With the existence of a Decision Support System for determining majors, this can help schools determine the direction of their students according to the criteria used.

c. The results of the Consistency Ratio AHP method produce a value of 0.0603577 . Where the value shows $93.96 \%$ that means consistent. 


\section{REFERENCES}

[1] Kemdikbud, "Peraturan Menteri Pendidikan dan Kebudayaan nomor 24 Tahun 2016 Tentang Kompetensi Inti Dan Kompetensi Dasar Pelajaran Pada Kurikulum 2013 Pada Pendidikan Dasar Dan Pendidikan Menengah," Peratur. Menteri Pendidik. dan Kebud., vol. 2025, 2016.

[2] M. Fakhrur and M. Isa, "Sistem Pendukung Keputusan dalam Memilih Jurusan SMA Menggunakan Model Yager," J. Sains dan Seni ITS, vol. 4, no. 1, pp. 7-12, 2015.

[3] "Implementasi Metode Wp (Weighted Product) Untuk Mendukung Keputusan Penjurusan Siswa Di Sma Negeri 1 Grobogan,” J. Teknol. Inf. dan Komun., vol. 4, no. 2, 2016.

[4] I. N. Farida and R. Firliana, "Implementasi Metode Profile Matching Untuk Evaluasi Potensi Akademik Penjurusan Siswa MAN 2 Kota Kediri," J. INFOTEL - Inform. Telekomun. Elektron., vol. 8, no. 2, p. 156, 2016.

[5] F. Purnama, "Sistem Pendukung Keputusan Pemilihan Jurusan Bagi Siswa Sma N 8 Merangin Dengan Metode Simple Additive Weighted ( Saw )," pp. 9-13.

[6] B. Daniawan, "Evaluation of Lecturer Teaching Performance Using AHP and SAW Methods," bit-Tech, vol. 1, no. 2, 2018.

[7] Y. Bassil, "A Simulation Model for the Waterfall Software Development Life Cycle," vol. 2, no. 5, 2012.

[8] P. T. Kazibudzki, "On Some Discoveries in the Field of Scientific Methods for Management within the Concept of Analytic Hierarchy Process," Int. J. Bus. Manag., vol. 8, no. 8, pp. 22-30, 2013.

[9] Saaty T.L., "Decision making with the analytic hierarchy process," Int. J. Serv. Sci., vol. 1 , no. 1, p. 83, 2008.

[10] M. Marimin and N. Maghfiroh, Aplikasi Teknik Pengambilan Keputusan Dalam Manajemen Rantai Pasok. 2010.

[11] S. Eniyati, "Perancangan Sistem Pendukung Pengambilan Keputusan untuk Penerimaan Beasiswa dengan Metode SAW ( Simple Additive Weighting ),” vol. 16, no. 2, pp. 171177, 2011.

[12] Kurnia, Y., \& Sagara, D. (2017). Perancangan Aplikasi Penentu Jurusan IPA atau IPS Pada SMA Menggunakan Fuzzy Logic. Tech-E, 1(1), 15 - 21. doi:10.31253/te.v1i1.15

\section{BIOGRAPHY}

Devita Amalia Pertiwi, Graduated from the Information Systems Study Program (S1) atFaculty Sains and Technology, Buddhi Dharma University 2019.

Benny Daniawan, Graduated from the Information Technology Study Program (S1) in 2011, continued his Masters in Information Systems in 2014 and graduated in 2016. He is currently a Lecturer in Information Systems Study Program, Buddhi Dharma University.

Yuki Gunawan, He is currently a Lecturer in Information Systems Study Program, Buddhi Dharma University. 